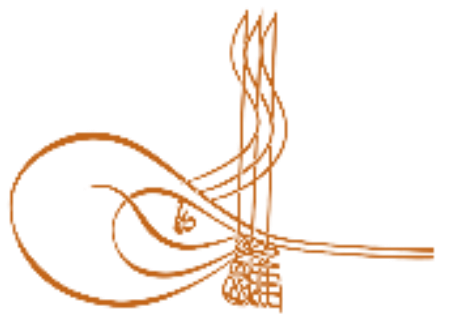

www.turkishstudies.net/turkishstudies
Turkish Studies

eISSN: $1308-2140$

Research Article / Araştırma Makalesi

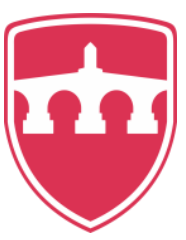

INTERNATIONAL

BALKAN

UNIVERSITY

Sponsored by IBU

\title{
Farklı Tür Metinler için Dinlediğini Anlama Başarı Testlerinin Geliştirilmesi*
}

Improving Listening Comprehension Test for Different Types Texts

\author{
Bahar Doğan Kahtalı ${ }^{* *}$ - İlhan Erdem ${ }^{* * *}$
}

\begin{abstract}
The aim of this study is to develop valid and reliable measurement tools to measure the comprehension skills of middle school seventh grade students in different text types. In the test development process, in accordance with a previously prepared table of specifications; a pool was created at different levels and question types. Before the test was applied, expert opinions were taken and a pilot study was conducted with five students. The draft achievement test prepared in the poetry genre was applied to184 students, the test in the narrative genre was applied to 212 students and the achievement test prepared in the informative text genre was applied to 197 students. The data were analyzed by TAP. In order to test the validity of multiple choice and right and wrong type questions, the difficulty and discrimination levels of each question were determined and some questions were excluded from the tests. Kuder-Richardson 20 (KR 20) value was examined for the reliability of multiple choice and right and wrong type items. Answer keys of open-ended questions were prepared in accordance with detailed scoring. Apart from the researcher, two field experts examined 50 data for each test with open-ended questions according to the answer key. In order to determine the consistency among raters, intra-cluster correlation analysis (IRB) was performed using SPSS. There are 14 items, 6 multiple choice, 3 right-wrong type and 5 open-ended, in the valid and reliable final form of the poetry achievement test. There are 14 items, 11 multiple choice and 3 open-ended, valid and reliable final test of the narrative text type achievement test. There are 14 items in the current and reliable final form of the informative text type achievement test, 8 multiple choice, 3 right-wrong type and 3 open-ended.
\end{abstract}

\section{Structured Abstract: Introduction}

Listening is the first language skill acquired and is very important in terms of providing a basis for other skills. Listening is defined as the process of taking visual and auditory stimuli, paying attention to them, evaluating and interpreting them. The fact that listening is very important in human relations and it is the basis for

\footnotetext{
* Bu çalışma araştırmacının İnönü Üniversitesi Eğitim Bilimleri Enstitüsünde yaptığı "Strateji Temelli Dinleme Etkinliklerinin Yedinci Sınıf Öğrencilerinin Dinleme Becerisiyle Strateji Kullanma Düzeyine Etkisi” başlıklı doktora tezinden üretilmiştir.

** Dr. Öğr. Üyesi, İnönü Üniversitesi, Eğitim Fakültesi, Türkçe ve Sosyal Bilimler Eğitimi Bölümü Asst. Prof. Dr., Inonu University, Faculty of Education, Turkish and Social Sciences Education ORCID 0000-0001-6184-2306

bahar.dogan@inonu.edu.tr

**** Prof. Dr., İnönü Üniversitesi, Eğitim Fakültesi, Türkçe ve Sosyal Bilimler Eğitimi Bölümü

Prof. Dr., Inonu University, Faculty of Education, Turkish and Social Sciences Education

ORCID 0000-0002-4244-6225

ilhan.erdem@inonu.edu.tr

Cite as/ Atıf: Doğan Kahtalı, B., Erdem, İ (2020). Farklı tür metinler için dinlediğini anlama başarı testlerinin geliştirilmesi, Turkish Studies, 15(2), 891-909. https://dx.doi.org/10.29228/TurkishStudies.42091

Received/Geliş: 10 March/Mart 2020

Accepted/Kabul: 29 April/Nisan 2020

Copyright $(\mathrm{C}$ INTAC LTD, Turkey
} 
academic success makes it important to develop this skill. In order to improve listening skills, purpose and acquisition sentences are included in 2006 Primary Education Turkish Course Curriculums (PETCC). However, it can be said that there is deficiency in assessment and evaluation of listening acquisitions. When the relevant literature was examined, it was observed that there were no valid and reliable achievement tests that measure seventh grade students' listening skills in different genres. The starting point of this study was the necessity to measure the listening comprehension skills of the students with measurement tools including different question styles in accordance with their level of knowledge, inference and critical thinking in poetry, narrative and informative text types. It is thought that the achievement tests to be prepared with these features will fill the gap in the field.

The aim of this study is to develop valid and reliable measurement tools to measure the listening comprehension skills of secondary school seventh grade students in different genres of text.

\section{Method}

This research, based on the survey model, was conducted on $7^{\text {th }}$-grade students attending four different secondary schools in Battalgazi district of Malatya province. Since the developed achievement tests were used as a measurement tool in the researcher's doctoral thesis. The draft achievement test prepared in the poetry genre was applied to184 students, the test in the narrative genre was applied to 212 students and the achievement test prepared in the informative text genre was applied to 197 students. Initially, the students listened to / watched the text using the smart board. Subsequently, the prepared draft achievement test was applied to them.

The necessity of using different types of texts in the development of comprehension skills in Turkish lessons is emphasized in PETCC (MEB, 2006). For this reason, concerning the achievement test, the researcher created four different text pools in poetry, narrative and informative text genres through literature review. The opinions of four Turkish education experts were asked about the suitability of the texts to the student's level in terms of style and length, about whether the texts will attract the attention of the students, title-content compliance, vocabulary diversity, suitability in terms of acquisitions and whether the texts feature certain characteristics included in the listening/watching texts in the PETCC (MEB, 2006). As a result of expert opinions, Kara Toprak, Gürültü Kirliliği, and Bitlis Kalesi Efsanesi were chosen for the achievement test.

A multiple-choice, true-false type and open-ended question pool was created for the selected texts. In order to determine the content validity of the tests, a table of specifications was prepared. The questions were prepared in accordance with the knowledge, inference and critical thinking levels of students.

Seven experts in Turkish education field and two curriculum experts were asked their opinions about the questions prepared. The experts expressed their opinions in terms of the number, applicability, objectivity and scorability of the questions included in the achievement tests. In addition, the experts expressed their views and suggestions regarding the content and face validity of the test. In order to determine the comprehensibility of the questions, the test was read by five seventh grade students who were not included in the sample.

By analyzing the obtained data in the Test Analysis Program (TAP), power and distinctiveness levels and reliability of the items of the multiple choice and true-false questions were determined. The items with a total correlation of less than 30 and with poor distinctiveness or need to be improved were removed from the test. For the reliability of the multiple-choice and true-false type items, Kuder-Richardson 20 (KR 20) value was used. The answer keys for open-ended questions were prepared in accordance with detailed scoring. Apart from the researcher, two different field experts also examined the open-ended questions in 50 data determined randomly for each test according to the answer key. In order to determine consistency among scorers, intracluster correlation analysis (ICC) was performed on the obtained results through the SPSS.

\section{Findings, Result and Discussion}

Within the scope of this research, three valid and reliable achievement tests were developed in poetry, narrative and informative text genres for the seventh grade students.

In the poetry genre, a total of 20 questions were prepared consisting of ten multiple-choice, five truefalse, and five open-ended type questions. As a result of the analyses conducted on multiple choice and truefalse questions, for the valid and reliable final form of the poetry-genre achievement test, there are totally fourteen items including six multiple-choice, three true-false and five open-ended type. The six multiple choice 
and three true-false type questions have a value of 6 points. Of the five open-ended questions, the thirteenth question has a value of 6 points and the others have a value of 10 points. The highest possible score from the test is 100 points.

In the achievement test prepared for the narrative text genre, there are nineteen questions, sixteen of which are multiple-choice and three of which are open-ended. As a result of the analysis on the multiple-choice and true-false-type questions, there are totally fourteen items, including eleven multiple-choice and three openended in the current valid and reliable narrative text genre achievement test. The test score is evaluated over 100 points, the first 11 questions being 6 points, the twelfth question 4 , and the thirteen and fourteenth questions being 15 points.

In the achievement test prepared for the informative text type, there are nineteen questions, including eleven multiple-choice, five true-false, and three open-ended type questions. As a result of the analysis on the multiple-choice and true-false type questions, there are totally fourteen items, including eight multiple-choice, three true-false, and three open-ended type questions in the current valid and reliable informative text type achievement test. Of the items, eight multiple choice and three true false type questions have a value of 6 points, the twelfth question is 4 points, and value of the thirteenth and fourteenth questions is 15 points. The highest possible score of the test is 100 points.

Keywords: Turkish language Education, listening comprehension, achievement test, validity, reliability.

Öz: $\mathrm{Bu}$ çalışmanın amacı ortaokul yedinci sınıf öğrencilerinin farklı metin türlerinde dinlediğini anlama becerilerini ölçmek için geçerli ve güvenilir ölçme araçları geliştirmektedir. Test geliştirme sürecinde, önceden hazırlanan belirtke tablosuna uygun olarak; farklı düzeyler ve soru türlerinde havuz oluşturulmuştur. Test, uygulanmadan önce uzman görüşleri alınmış ve beş öğrenci ile pilot çalışması yapılmıştır. Şiir türü için hazırlanan taslak başarı testi 184 öğrenciye; öyküleyici metin türü hazırlanan taslak başarı testi, 212 öğrenciye ve bilgilendirici metin türü için hazırlanan başarı testi 197 öğrenciye uygulanmıştır. Veriler Test Analiz Programı (TAP) ile analiz edilmiştir. Çoktan seçmeli ve doğru yanlış türündeki soruların geçerliliğini test etmek üzere her bir sorunun güçlük ve ayırt edicilik düzeyleri belirlenmiş, bazı sorular testlerden çıkarılmıştır. Çoktan seçmeli ve doğru yanlış tipi maddelerin güvenirliği için Kuder-Richardson 20 (KR 20) değerine bakılmıştır. Açık uçlu soruların cevap anahtarları detaylı puanlamaya uygun şekilde hazırlanmıştır. Araştırmacı dışında iki alan uzmanı, her test için 50 veriyi açık uçlu soruları cevap anahtarına göre incelemiştir. Puanlayıcılar arasındaki tutarlılığı belirlemek üzere elde edilen sonuçlar üzerinde SPSS kullanılarak küme içi korelasyon analizi (KİK) yapılmıştır. Şiir türü başarı testinin geçerli ve güvenilir son şeklinde, 6 çoktan seçmeli, 3 doğru-yanlış tipi ve 5 açık uçlu olmak üzere toplam 14 madde bulunmaktadır. Öyküleyici metin türü başarı testinin geçerli ve güvenilir son şeklinde, 11 çoktan seçmeli ve 3 açık uçlu olmak üzere toplam 14 madde bulunmaktadır. Bilgilendirici metin türü başarı testinin geçerli ve güvenilir son şeklinde, 8 çoktan seçmeli, 3 doğru yanlış tipi ve 3 açık uçlu olmak üzere toplam 14 madde bulunmaktadır.

Anahtar Kelimeler: Türkçe Eğitimi, dinlediğini anlama, başarı testi, geçerlilik, güvenirlik.

\section{Giriş}

Anlama becerilerinin ilk edinileni olan ve kişinin ilk okuldan üniversiteye tüm eğitim hayatında en sık kullandığı beceri olan dinleme (Mackay, 1997); görsel ve işaretsel uyarıcıları alma, onlara dikkat etme, onları değerlendirme, anlamlandırma ve tepki verme adımlarının bir süreçte aktif olarak harekete geçmesiyle gerçekleşen bir beceridir (Calp, 2010; Doğan, 2011; Gürüz ve Temel Eğinli, 2013; Özbay, 2009; Wolvin ve Coakley, 1996).

Dinlemenin iletişimde oldukça önemli olması ve akademik başarı için temel oluşturması bu becerinin geliştirilmesini önemli kılmaktadır. İlköğretim Türkçe Dersi Öğretim Programı’nda (İTDÖP) (MEB, 2006) dinleme becerilerini geliştirmek üzere amaç ve kazanım cümlelerine yer verilmiştir. Bununla birlikte ölçme ve değerlendirme konusunda genel olarak Türkçe dersine yönelik ölçme ve değerlendirmenin nasıl olması gerektiği İTDÖP'te belirtilmiştir. Türkçe dersi dört temel dil becerisini geşiltirmeyi hedefleyen bir ders olmasına rağmen Türkiye'de sınıf içi uygulamalarda 
genellikle okuma ve kısmen yazma becerisinin ölçüldüğü ve bu iki beceriye göre öğrencinin akademik başarısının belirlendiği bilinmektedir. Ayrıca ulusal ölçekte yapılan ortaöğretime geçiş sınavlarında da sadece öğrencinin okuduğunu anlama becerisinin ölçüldüğü bir gerçektir. Bu bilgiler doğrultusunda diğer becerilere temel oluşturan dinleme becerisinin ölçme ve değerlendirme boyutunun eksik kaldığı söylenebilir. İlgili literatür incelendiğinde yedinci sınıf öğrencilerinin farklı türlerde dinlediğini anlama becerilerini ölçen geçerli ve güvenilir başarı testlerinin bulunmadığ görülmüştür. Öğrencilerin şiir, öyküleyici ve bilgilendirici metin türlerinde bilgi, çıkarım ve eleştirel düşünme düzeyine uygun, farklı soru tarzlarını içeren ölçme araçlarıyla dinlediğini anlama becerilerinin ölçülmesi gerekliliği bu araştırmanın çıkış noktasını oluşturmuştur. Bu özelliklerde hazırlanacak başarı testlerinin alandaki boşluğu dolduracağı düşünülmektedir.

$\mathrm{Bu}$ araştırmanın amacı ortaokul yedinci sınıf öğrencilerinin farklı metin türlerinde dinlediğini anlama becerilerini ölçmek için geçerli ve güvenilir ölçme araçları geliştirmektedir. Araştırma İTDÖP'te (MEB, 2006) yer alan dinleme becerisi kazanımlarıla ve yedinci sınıf öğrencileriyle sınırlıdır. Araştırma İTDÖP (MEB, 2006) ile sınırlı olduğu için 2017, 2018 ve 2019 Programları'na çalışmada yer verilmemiştir.

\section{Yöntem}

\section{Araştırmanın Modeli ve Çalışma Grubu}

Araştırma geçmişte ya da halen var olan bir durumu olduğu gibi ortaya koymayı amaçlayan tarama modelinde (Karasar, 2006) yapılmıştır. Bu araştırma kapsamında da yedinci sınıf öğrencilerinin dinlediğini anlama becerilerini ölçmek üzere bir başarı testi geliştrilmeye çalışılmıştır.

Araştırma kapsmamıda geliştirilen testler, 2015-2016 öğretim yılında Malatya ili Battalgazi ilçesinde yer alan dört farklı ortaokulda 7. sınıf düzeyinde öğrenimine devam eden öğrencilere uygulanmıştır. Şiir türünde hazırlanan taslak başarı testi, 184 öğrenciye; öyküleyici türünde hazırlanan taslak başarı testi, 212 öğrenciye ve bilgilendirici metin türünde hazırlanan başarı testi 197 öğrenciye uygulanmıştır. Her bir metin farklı bir günde öğrencilere akıllı tahtadan dinletilmiş/izletilmiştir ve hemen sonra ara vermeden hazırlanan taslak başarı testi uygulanmıştır. Testler şiir metni, öyküleyici metin vebilgilendirici metin türlerinde dinlediğini anlamaya yönelik olduğu için her bir test farklı günlerde uygulanmıştır. Bu nedenle öğrenci sayıları değişmektedir. Bir ders saatinde metinler akıllı tahta aracılığıyla öğrencilere iki kez dinletilmiş (şiir metni izletilmiş) ve daha sonra testler uygulanmıştır. Bu testler araştırmacının doktora tezinin ön test ve son testinde ölçme aracı olarak kullanmak üzere geliştirdiği testlerdir. Araştırmacı, strateji temelli dinleme eğitiminin yedinci sınıf öğrencilerinin dinleme becerisi üzerine etkisini belirlemek için bu başarı testlerini geliştirmiş ve sonrasında kullanmıştır.

\section{Test Geliştirilme Süreci}

Test geliştirme sürecinin aşamaları Şekil 1'de gösterilmiştir.

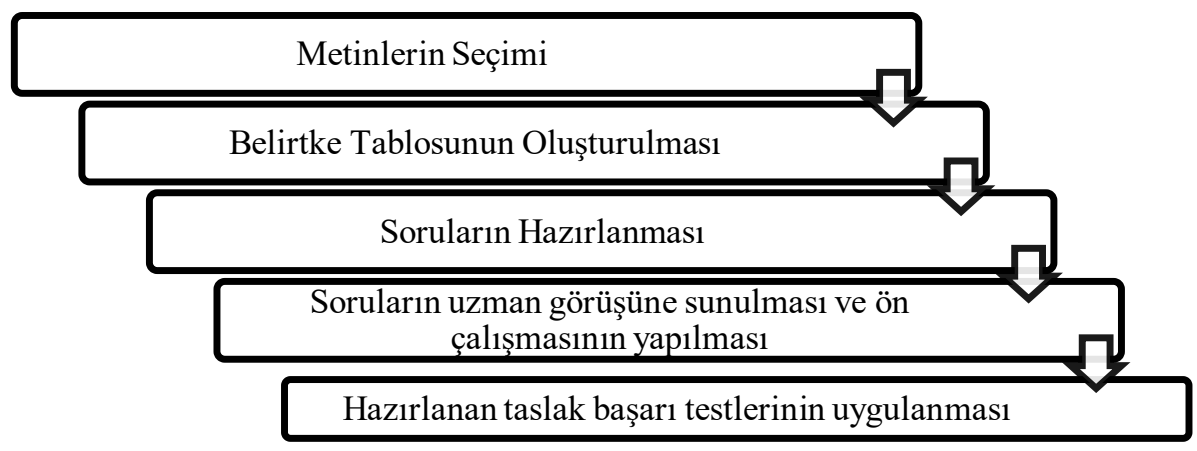

Şekil 1. Test Geliştirme aşamaları 


\section{Metinlerin Seçimi}

Türkçe dersinde anlama becerilerinin geliştirilmesinde farklı türden metinlerin kullanılmasının gerekliliği İTDÖP’te (MEB, 2006) önemle vurgulanmaktadır. Bu nedenle araştırmacı tarafından farklı dinleme-izleme kaynakları (Youtube'da ders içeriği olabilecek materyaller, farklı y1llara ait Türkçe ders kitaplarında yer alan dinleme metinleri, Türkçenin Sesi Radyosu ve Denizkültür'ün Sesli Edebiyat Yapımları vb.) taranarak başarı testi için şiir, öyküleyici ve bilgilendirici metin türlerinde dört farklı metin havuzu oluşturulmuştur. Söz konusu metinlerin üslup ve uzunluk açısından öğrenci seviyesine uygunluğu, öğrencilerin ilgilerini çekip çekmeyeceği, başlık-içerik uyumu, kelime çeşitliliği, kazanımlar açısından uygunluğu ve İTDÖP'te (MEB, 2006) yer alan dinleme/izleme metinlerinde bulunması gereken özellikleri taşıyıp taşımadığı gibi kriterler açısından uygunluğuna ilişkin dört Türkçe eğitimi uzmanından e- posta aracıllğıyla görüş alınmıştır. Uzmanlardan her bir kritere ilişkin evet/uygun; hayır/uygun değil şeklinde görüş bildirmeleri istenmiştir. Uzmanların evet cevapları bir puan olarak belirlenmiş ve yedi kritere göre en çok puan alan metinler Tablo 1'de belirtilmiştir.

Tablo 1: Başarı Testi İçin Seçilen Metinler ve Uzman Görüşlerine Göre Metinlerin Aldığı Puanlar

\begin{tabular}{lll}
\hline Metnin Türüi & Metin isimleri-yazarı ve türü̈ & $\begin{array}{l}\text { Top. } \\
\text { Puanlar }\end{array}$ \\
\hline Şiir metinleri & Kara Toprak-Aşık Veysel Şatıroğlu-Video metni**** & 27 \\
& 7 Tane Erik Ağacı-Bedri Rahmi Eyüpoğlu-Dinleme metni & 17 \\
& Bakardım Güneş Avuçlarımda-Beşir Ayvazoğlu-Dinleme metni & 8 \\
& Kitaplarla Kurulan Dostluk-Coşkun Ertepınar-Dinleme metni & 19 \\
\hline Bilgilendirici & Çevre Bilinci* & 22 \\
metinler & Yeraltı Suları* & 21 \\
& Atık Piller* & 25 \\
& Gürültü Kirliliği* & 26 \\
\hline Öyküleyici & Kirazlar-Reşat Nuri Güntekin-Dinleme metni*** & 19 \\
metinler & Bingöller ve Kuş Gölü Efsanesi**- & 13 \\
& Bitlis Kalesi Efsanesi** & 22 \\
& Alacadağ'ın Devi Efsanesi** & 19 \\
\hline
\end{tabular}

* Ayşe Yücel tarafından Türkçenin Sesi Radyosunda yayınlanan Yeşil Dünyamız programı için hazırlanan dinleme metinleridir.

** Kültür ve Turizm Bakanlığı Araştırma ve Eğitim Genel Müdürlüğü tarafından Türkçenin Sesi Radyosunda yayınlanan Anadolu Anlatıları Programı için hazırlanan dinleme metinleridir.

***Denizbank Finansal Hizmetler Grubu. (2007). Sesli Edebiyat Öyküler Sesleniyor Projesi. Deniz Kültür Sesli Edebiyat Dizisi 1. Denizbank Kültür Sanat Yayıncılık, cd-6 (5. metin).

****Şatıroğlu, A. V. (2013). Kara Toprak. Kalan Müzik. Web: https://www.youtube.com/watch?v=2cGANgDZPj8 adresinden 05.03.2020'de alınmıştır.

Tablo1'de başarı testi havuzu için seçilen metinler, yazarları ve türleri belirtilmiştir. Kaynakları dipnotta belirtilmeyenler metinler, Türkçe ders kitaplarında yer alan dinleme metinleridir. Tablo 1'de de görüldügü üzere uzman görüşleri neticesinde Kara Toprak video metni ile Gürültü Kirliliği ve Bitlis Kalesi Efsanesi dinleme metinleri başarı testi için seçilmiştir.

\section{Belirtke Tablosunun Oluşturulması, Soruların Hazırlanması ve Uygulanması}

Seçilen metinlere ilişkin çoktan seçmeli, doğru yanlıș ve açık uçlu türünde soru havuzu oluşturulmuştur. Testlerin kapsam geçerliliğini belirlemek üzere İTDÖP’te (MEB, 2006) yer alan dinleme /izleme kazanımları dikkate alınarak belirtke tablosu hazırlanmıştır (Ek 2). Oluşturulan sorular bilgi, çıkarım ve eleştirel düşünme düzeylerine uygun olarak hazırlanmıştır. Okuma Becerileri Dersi Öğretim Programı'nda (MEB, 2012) anlama becerileri için bilgi, çıkarım ve eleştirel düşünme düzeyinde sorular sorulması beklenmektedir. Dinleme de bir anlama becerisi olduğu için bu başarı testinde de bu ölçütlere göre sorular hazırlanmıştır. 


\begin{abstract}
"Bilgi soruları, metinde anlatılanların herhangi bir yorumlama ya da açıklamaya ihtiyaç duyulmadan, metinde yer aldığı şekliyle anlaşılıp anlaşılmadığını kontrol etme amacını taşıyan sorulardır. Çıkarım soruları ile okuyucu metne ilişkin yorum yaparken açıkça ifade edilmemiş bilgi ve düşünceleri keşfederek ya da metinde ifade edilen çeşitli bilgi ve düşünceler arasında ilişkiler kurarak belirli sonuçlara ulaşır. Eleştirel düşünme soruları, okuyucuların metinde doğrudan ifade edilen ya da kendi çıkarımlarıyla ortaya çıkardığı anlamları; gerçek dünya bilgisiyle toplumun değer yargılarıyla, diğer metinlerle karşılaştırarak değerlendirmeleri ve çeşitli sonuçlara ulaşmalarını amaçlayan sorulardır" (MEB, 2012: 10-11).
\end{abstract}

Hazırlanan sorular için ayrıca Türkçe eğitimi alanında uzman yedi kişinin ve eğitim programları alanında uzman iki kişinin görüşleri e-posta yoluyla alınmıştır. Uzmanlar, başarı testlerinde yer alan soruların sayısı, uygulanabilirliği, objektifliği ve puanlanabilirliği açısından görüş bildirmişlerdir. Ayrıca uzmanlar testin kapsam ve görünüş geçerliliği ile ilgili de görüşlerini ve önerilerini belirtmişlerdir. Test, soruların anlaşılırlı̆̆ını belirlemek için örneklem dışından beş, yedinci sınıf öğrencisine okutulmuştur. Öğrencilere metinler dinletilmiş ya da izletilmiş ve sonrasında soruların anlaşılırlığı açısından testi değerlendirmeleri istenmiştir. Öğrenci görüşleri neticesinde bazı soru köklerinde değişiklik yapılmıştır. Uzmanlardan alınan görüşler neticesinde başarı testi şekillendirilerek uygulamaya geçilmiştir. Seçilen okullarda yedinci sınıf öğrencilerine akıllı tahta kullanılarak önce metinler dinletilmiş/izletilmiştir. Daha sonra hazırlanan taslak başarı testlerinin her biri farklı günlerde uygulanmıştır.

\title{
Verilerin Analizi
}

Elde edilen veriler Test Analiz Programında (TAP) incelenerek çoktan seçmeli ve doğru yanlış tipi soruların madde güçlük ve ayırt edicilik düzeyleri ve güvenirlikleri belirlenmiştir. Madde toplam korelasyonu .30'un altında olan ve ayırt ediciliği zayıf ya da geliştirilmesi gereken maddeler testten çıkarılmıştır. Çoktan seçmeli ve doğru yanlış tipi maddelerin güvenirliği için KuderRichardson 20 (KR 20) değerine bakılmıştır. Açık uçlu soruların cevap anahtarları detaylı puanlamaya uygun şekilde hazırlanmıştır. Araştırmacı dışında iki farklı alan uzmanı da her test için seçkisiz olarak belirlenen 50 verideki açık uçlu soruları cevap anahtarına göre incelemişlerdir. Puanlayıcılar arasındaki tutarlılı̆̆ 1 belirlemek üzere elde edilen sonuçlar üzerinde SPSS kullanılarak kümeiçi korelasyon analizi (KİK) yapıldı. "Shrout ve Fleiss (1979) tarafından geliştirilen küme içi korelasyon analizi daha çok gözlemcilerin veya değerlendiricilerin yaptıkları puanlamanın tutarlılık güvenirliğini belirlemek için kullanılır” (aktaran Şencan, 2005: 272).

Shrout ve Fleiss küme içi korelasyon analizi için üç model önermektedir ve araştırmacılar kendi araştırmalarının amacına uygun olarak bu modellerden birini seçmektedirler. $\mathrm{Bu}$ araştırmada üç farklı puanlayıcı pilot uygulamaya katılan öğrencilerden seçkisiz olarak belirli sayıdaki öğrenciyi değerlendirdikleri için Şencan'ın (2005) aktardığı modellerden KIK (1, k) araştırma için uygun görülmüştür. Bu modelde "rasgele seçilen kişiler, çok sayıda farklı gözlemciler tarafından değerlendirilir. Çok sayıda gözlemcinin yaptı̆̆ değerlendirmelerin ortalamaları alınarak hesaplama yapılır. SPSS’te "Avarage Measure Intraclass Correlation" başlığı altında gözlemcilerin ortalama değerlendirme güvenirlik katsayısı elde edilir”" (Şencan, 2005: 275).

Çoktan seçmeli ve doğru yanlış tipi maddelerin güvenirliği için Kuder-Richardson 20 (KR 20) değerine bakılmıştır.

\section{Bulgular}

Araştırma kapsamında şiir, öyküleyici ve bilgilendirici metin türlerinde üç farklı başarı testi geliştirmek amaçlanmıştır. Söz konusu testlerin geçerlilik ve güvenirliğine ilişkin bulgulara bu bölümde yer verilmektedir. 
Şiir metni olarak seçilen Âşıłk Veysel'in “Kara Toprak" şiiri video içerikli bir metindir. Bu metne yönelik taslak başarı testinde on çoktan seçmeli, beş doğru-yanlış tipi ve beş açık uçlu soru bulunmaktadır. Söz konusu başarı testi 184 yedinci sınıf öğrencisine uygulanmıştır. Çoktan seçmeli ve doğru yanlış tipi sorulara ait istatistiki bilgiler Tablo 2'de yer almaktadır:

Tablo 2: Şiir Türünde Dinlediğini/Izzlediğini Anlama Başarı Testi’nin (ŞBT) Madde Güçlük ve Ayırt Edicilik İndeksleri

\begin{tabular}{llllll}
\hline $\begin{array}{l}\text { Madde } \\
\text { No }\end{array}$ & $\begin{array}{l}\text { Madde } \\
\text { Güçlük İn. }\end{array}$ & $\begin{array}{l}\text { Madde Ayrrt Edicilik } \\
\text { İndeksi }\end{array}$ & $\begin{array}{l}\text { Madde } \\
\text { Korelasyonu }\end{array}$ & $\begin{array}{l}\text { Toplam } \\
\text { Testten } \\
\text { maddeler }\end{array}$ & çıarılan \\
\hline 1 & .26 & .57 & .52 & & \\
2 & .82 & .40 & .44 & \\
3 & .87 & .32 & .40 & \\
4 & .63 & .52 & .50 & \\
5 & .93 & .21 & .34 & $*$ \\
6 & .33 & .34 & .24 & \\
7 & .55 & .47 & .37 & $*$ \\
8 & .65 & .63 & .53 & \\
9 & .91 & .25 & .37 & \\
10 & .17 & .27 & .04 & \\
11 & .97 & .02 & .56 & \\
12 & .80 & .47 & .42 & & \\
13 & .83 & .36 & .28 & & \\
14 & .93 & .14 & .53 & & \\
15 & .82 & .41 & & & \\
\hline
\end{tabular}

Tablo 2'de çoktan seçmeli (1.-10. maddeler) ve doğru-yanlış tipi (11.-15. maddeler) maddelerinin madde güçlük indeksi, madde ayırt edicilik indeksi ve madde toplam korelasyonları yer almaktadır. ŞBT'de madde toplam korelasyonu .30 'un altında olan ve ayırt ediciliği zayıf olan $(<.19)$ ve geliştirilmesi gereken $(.20-.29$ arasi) altı madde $(5,6,9,10,11$ ve 14 . maddeler) testten çıkarılmıştır. Testin son hâlinde altı çoktan seçmeli, üç doğru-yanlış tipi ve beş açık uçlu olmak üzere toplam on dört madde bulunmaktadır.

Çoktan seçmeli ve doğru yanlış tipi maddelerin güvenirliği için Kuder-Richardson 20 (KR 20) değerine bakılmıştır. "KR 20 formülü az sayıda maddeden oluşan (10-15 madde gibi) bilgi testleri için uygulanmışsa .50 dahi güvenilir kabul edilebilir" (Şencan, 2005: 135). ŞBT’nin de on beş maddesi analiz edildiği için KR $20=.56$ olarak belirlenen testin sonuç olarak geçerli ve güvenilir olduğu söylenebilir.

Öyküleyici metnin başarı testi için Yunus Emre Enstitüsüne ait Türkçenin Sesi Radyosu kapsamında T.C. Kültür ve Turizm Bakanlığı Araştırma ve Eğitim Genel Müdürlüğü (2016) tarafindan hazırlanan Anadolu Anlatıları programında yer alan "Bitlis Kalesi Efsanesi" adlı bir dinleme metni seçilmiştir. Bu metne yönelik hazırlanan taslak başarı testinde on altı çoktan seçmeli ve üç açık uçlu olmak üzere on dokuz soru bulunmaktadır. Söz konusu taslak başarı testi 212 yedinci sınıf öğrencisine uygulandı. Testin çoktan seçmeli maddelere ilişkin analiz sonuçları Tablo 3'te yer almaktadir: 
Tablo 3: Öyküleyici Metin Türünde Dinlediğini Anlama Başarı Testi’nin (ÖBT) Madde Güçlük ve Ayırt Edicilik İndeksleri

\begin{tabular}{llllll}
\hline $\begin{array}{l}\text { Madde } \\
\text { No }\end{array}$ & $\begin{array}{l}\text { Madde } \\
\text { Güçlïk İn. }\end{array}$ & $\begin{array}{l}\text { Madde Ayırt Edicilik } \\
\text { İndeksi }\end{array}$ & $\begin{array}{l}\text { Madde } \\
\text { Korelasyonu }\end{array}$ & $\begin{array}{l}\text { Toplam } \\
\text { Testten } \\
\text { maddeler }\end{array}$ & çıarılan \\
\hline 1 & .67 & .25 & .31 & & \\
2 & .39 & .52 & .46 & & \\
3 & .65 & .45 & .42 & & \\
4 & .76 & .57 & .62 & & \\
5 & .55 & .54 & .47 & & \\
6 & .41 & .46 & .43 & & \\
7 & .67 & .24 & .24 & & \\
8 & .83 & .20 & .31 & & \\
9 & .73 & .25 & .28 & & \\
10 & .42 & .38 & .33 & & \\
11 & .74 & .44 & .46 & & \\
12 & .66 & .42 & .43 & & \\
13 & .49 & .36 & .38 & & \\
14 & .81 & .43 & .55 & & \\
15 & .39 & .58 & .50 & & \\
16 & .16 & .25 & .16 & & \\
\hline
\end{tabular}

Tablo 3'te çoktan seçmeli maddelerin madde güçlük indeksi, madde ayırt edicilik indeksi ve madde toplam korelasyonları yer almaktadır. ÖBT'de madde toplam korelasyonu .30'un altında olan ve ayırt ediciliği zayıf olan (<.19) ve geliştirilmesi gereken $(.20$ - .29 arası) beş madde $(1,7,8,9$ ve 16. maddeler) testten çıkarılmıştır. ÖBT'nin son hâlinde on bir çoktan seçmeli ve üç açık uçlu olmak üzere toplam on dört madde bulunmaktadır. Çoktan seçmeli ve doğru yanlış tipi maddelerin güvenirliği için KR 20 değerine bakılmıştır. KR 20=.61 olarak belirlenen testin sonuç olarak geçerli ve güvenilir olduğu söylenebilir (Şencan, 2005).

Bilgilendirici metnin başarı testi için Yunus Emre Enstitüsüne ait Türkçenin Sesi Radyosu kapsamında Yücel (2016) tarafından hazırlanan Yeşil Dünyamız programında yer alan "Gürültü Kirliliği" adlı bir dinleme metni seçilmiştir. Bu metne yönelik hazırlanan taslak başarı testinde on bir tane çoktan seçmeli, beş doğru-yanlış tipi ve üç açık uçlu olmak üzere on dokuz soru bulunmaktadır. Söz konusu taslak başarı testi 197 yedinci sınıf öğrencisine uygulandı. Testin çoktan seçmeli maddelere ve doğru- yanlış tipi maddelerine ilişkin analiz sonuçları Tablo 4’te yer almaktadır. 
Tablo 4: Bilgilendirici Metin Türünde Dinlediğini Anlama Başarı Testi’nin (BBT) Madde Güçlük ve Ayırt Edicilik İndeksleri

\begin{tabular}{|c|c|c|c|c|c|c|}
\hline $\begin{array}{l}\text { Madde } \\
\text { no }\end{array}$ & $\begin{array}{l}\text { Madde Güçlük } \\
\text { İnd. }\end{array}$ & $\begin{array}{l}\text { Madde Ayırt Edicilik } \\
\text { İndeksi }\end{array}$ & $\begin{array}{l}\text { Madde } \\
\text { Korelasyonu }\end{array}$ & Toplam & $\begin{array}{l}\text { Testten } \\
\text { maddeler }\end{array}$ & çıkarılan \\
\hline 1 & .81 & .45 & .48 & & & \\
\hline 2 & .83 & .39 & .47 & & & \\
\hline 3 & .80 & .42 & .48 & & & \\
\hline 4 & .49 & .54 & .40 & & & \\
\hline 5 & .06 & -.02 & .00 & & * & \\
\hline 6 & .81 & .44 & .48 & & & \\
\hline 7 & .68 & .50 & .50 & & & \\
\hline 8 & .88 & .35 & .59 & & & \\
\hline 9 & .51 & .45 & .42 & & & \\
\hline 10 & 20 & .16 & .22 & & * & \\
\hline 11 & .29 & .24 & .27 & & * & \\
\hline 12 & .12 & .08 & .12 & & * & \\
\hline 13 & .93 & .12 & .24 & & * & \\
\hline 14 & .80 & .41 & .42 & & & \\
\hline 15 & .84 & .34 & .42 & & & \\
\hline 16 & .74 & .38 & .38 & & & \\
\hline
\end{tabular}

Tablo 4'te çoktan seçmeli (1.-11. maddeler) ve doğru-yanlış tipi (12.-16. maddeler) maddelerinin madde güçlük indeksi, madde ayırt edicilik indeksi ve madde toplam korelasyonları yer almaktadır. BBT'de madde toplam korelasyonu .30'un altında olan ve ayırt ediciliği zayıf olan $(<.19)$ ve geliştirilmesi gereken $(.20-.29$ arasi) beş madde $(5,10,11,12$ ve 13 . maddeler) testten çıkarılmıştır. BBT'nin son hâlinde sekiz çoktan seçmeli, üç doğru-yanlış tipi ve üç açık uçlu olmak üzere toplam on dört madde bulunmaktadır. Çoktan seçmeli ve doğru yanlış tipi maddelerin güvenirliği için KR 20 değerine bakılmıştır. KR $20=.60$ olarak belirlenen testin sonuç olarak geçerli ve güvenilir olduğu söylenebilir (Şencan, 2005).

ŞBT'de yer alan beş soru (16. -20. sorular), ÖBT ve BBT'de yer alan üçer açık uçlu soru (12.- 14. sorular) için pilot uygulamadan seçkisiz olarak her bir test için seçilen 50 veri, üç puanlayıcı tarafından değerlendirilmiştir. Puanlayıcılar arasındaki tutarlılığ için SPSS analiz programı yardımıyla küme içi korelasyon analizi (KIK) yapılmıştır. Analiz sonuçları Tablo 5'te yer almaktadır.

Tablo 5. Açık Uçlu Sorulara İlişkin Puanlayıcı Tutarlılı̆̆ (Küme içi korelasyon katsayısı)

\begin{tabular}{llll}
\hline & ŞBT & BBT & ÖBT \\
\hline Korelasyon katsayısı & .82 & .80 & .81 \\
\hline
\end{tabular}

Tablo 5 incelendiğinde üç farklı puanlayıcının ŞBT'de yer alan açık uçlu sorular için ortalama güvenirlik katsayısının .82; BBT'de yer alan açı uçlu sorular için .80 ve ÖBT'de yer alan açık uçlu sorular için .81 olduğu görülmektedir. "Fleiss (1981), Cichetti ve Sparrow'a (1981) göre hesaplanan küme içi korelasyon katsayılarından $\mathrm{r}<.40$ oranı zayıf; $\mathrm{r}=.40$ ile .59 arasındaki oranları orta; $r=.60$ ile .74 arasındaki oranlar iyi ve $r>.75^{\prime}$ ten yüksek olan oranlar mükemmel olarak kabul edilebilir" (aktaran Şencan, 2005: 279). Bu değerlere göre incelendiğinde açık uçlu soruları değerlendirmede puanlayıcılar arasında mükemmel uyum olduğu belirtilebilir. Yapılan analizler sonucunda başarı testlerine son şekli verilmiştir (Ek 1).

\section{Sonuç}

Araştırma kapsamında yedinci sınıf öğrencilerine yönelik şiir, öyküleyici ve bilgilendirici metin türlerinde geçerli ve güvenilir üç başarı testi geliştirilmiştir.

Şiir türünde ilk olarak on çoktan seçmeli, beş doğru-yanlış tipi ve beş açık uçlu sorudan oluşan toplam 20 soruluk bir test hazırlanmıştır. Çoktan seçmeli ve doğru-yanlış türündeki sorular 
üzerinde yapılan analizler sonucu şiir türü başarı testinin geçerli ve güvenilir son şeklinde altı çoktan seçmeli, üç doğru-yanlış tipi ve beş açık uçlu olmak üzere toplam on dört madde bulunmaktadır. Testte yer alan 1. ve 11. sorular bilgi düzeyinde, 14. soru eleştirel düşünme düzeyinde geri kalan sorular $(2,3,4,5,6,7,8,9,10,12,13)$ ise çıkarım düzeyindedir. Altı çoktan seçmeli ve üç doğruyanlış tipi sorunun puan değerleri 6 ' dır. Beş açık uçlu sorudan on üçüncü sorunun puan değeri 6 puan olup diğerlerinin değeri 10 puan olarak belirlenmiştir. Testten alınabilecek en yüksek puan 100 puandir.

Öyküleyici metin türüne yönelik hazırlanan başarı testinde ilk olarak on altı çoktan seçmeli ve üç açık uçlu olmak üzere on dokuz soru bulunmaktadır. Çoktan seçmeli ve doğru-yanlış türündeki sorular üzerinde yapılan analizler sonucu öyküleyici metin türü başarı testinin geçerli ve güvenilir son şeklinde on bir çoktan seçmeli ve üç açık uçlu olmak üzere toplam on dört madde bulunmaktadır. Testte yer alan 13. ve 14. sorular eleştirel düşünme düzeyinde; 8, 10, 11 ve 12. sorular çıkarım düzeyinde geri kalan sorular $(1,2,3,4,5,6,7,9)$ bilgi düzeyindedir. Test puanlamas 100 puan üzerinden olup ilk 11 soru 6 puan, on ikinci soru 4 ve on üç ile on dördüncü sorular 15 puan değerindedir.

Bilgilendirici metin türüne yönelik hazırlanan başarı testinde ilk olarak on bir tane çoktan seçmeli, beş doğru-yanlış tipi ve üç açık uçlu olmak üzere on dokuz soru bulunmaktadır. Çoktan seçmeli ve doğru-yanlış türündeki sorular üzerinde yapılan analizler sonucu bilgilendirici metin türü başarı testinin geçerli ve güvenilir son şeklinde sekiz çoktan seçmeli, üç doğru-yanlış tipi ve üç açık uçlu olmak üzere toplam on dört madde bulunmaktadır. Testte yer alan 13. ve 14. sorular eleştirel düşünme düzeyinde; 4, 5 ve 12. sorular çıkarım düzeyinde geri kalan sorular $(1,2,3,6,7,8,9,10$, 11) bilgi düzeyindedir. Sekiz çoktan seçmeli ve üç doğru yanlış tipi sorunun puan değeri 6 puan, on ikinci sorunun puan değeri 4 ve on üç ile on dördüncü soruların puan değeri $15^{\prime}$ tir. Testten alınabilecek en yüksek puan 100 puandır.

\section{Kaynakça}

Calp, M. (2010). Özel eğitim alanı olarak Türkçe öğretimi. (4. basım). Ankara: Nobel Yayıncılık.

Doğan, Y. (2011). Dinleme eğitimi. (1. basım). Ankara: Pegem Akademi Yayıncılık.

Gürüz, D. ve Temel Eğinli, A. (2013). İletişim becerileri, anlamak-anlatmak-anlaşmak. (2. baskı). Ankara: Nobel Yayınevi.

Karasar, N. (2006). Bilimsel araştırma yöntemi. Ankara: Nobel Yayın Dağıtım.

Kültür ve Turizm Bakanlığı Araştırma ve Eğitim Genel Müdürlüğü (2016, 11 Ocak). Bitlis Kalesi Efsanesi, Anadolu Anlatılart Radyo Programi. Web: http://turkceninsesi.yee.org.tr/programlar/anadolu-anlatilari/anadolu-anlatilari-3 adresinden 15.01.2016' da alınmıştır.

Mackay, I. (1997). Dinleme becerisi (çev. A. Bora ve O. Cankoçak). Ankara: İlkkaynak Kültür ve Sanat Ürünleri.

MEB. (2006). İlköğretim Türkçe dersi ögretim programı ve kılavuzu (6, 7, 8. sinıflar). Ankara: Devlet Kitapları Müdürlüğü Basımevi.

MEB. (2012). Ortaokul ve imam hatip ortaokulu okuma becerileri dersi ögretim programı. Ankara: Devlet Kitapları Müdürlügü Basımevi.

Özbay, M. (2009). Dinleme eğitimi. (1. Basım). Ankara: Öncü Kitap.

Şencan, H. (2005). Sosyal ve davranışsal ölçümlerde güvenilirlik ve geçerlilik. (1. basım). Ankara: Seçkin Yayıncılık 
Wolvin, A. and Coakley, C. G. (1996). Listening. (Fifth Edition). Boston: Mc Graw H.

Yücel, A. (2016a, 16 Şubat). Gürültü Kirliliği, Yeşil Dünyamız Radyo Programı, 4. bölüm. Web: http://turkceninsesi.yee.org.tr/programlar/yesil-dunyamiz/yesil-dunyamiz4 adresinden 16.02.2016'da alınmıştır. 
Ek 1.

\section{ŞİíR BAŞARI TESTİ (KARA TOPRAK)}

Aşağıdaki soruları izlediğiniz Kara Toprak metnine göre cevaplayınız. ( 9x6=54)

1. Aşağıdakilerden hangisi toprağın insanlara verdiklerinden biri değildir?
A. Koyun
B. Süt
C. Et
D. İnek

2. Şair, "Bir çekirdek verdim, dört bostan verdi." dizesinde toprağın hangi özelliğinden söz etmektedir?
A. Bereket
B. Çalışkanlık
C. Üretkenlik
D. Kitlik

3. Aşağıdakilerden hangisi şairin toprağa hissettiği duygulardan biri değildir?
A. Sevgi
B. Sadakat
C. Minnettarlık D. Pişmanlık

4. "Merhem çalıp yaralarım düzlüyor." dizesinde yer alan "çalmak" kelimesinin anlamca benzeri aşağıdaki cümlelerden hangisinde bulunmaktadır?
A. Gözlerinin rengi maviye çalıyordu.
B. O, çok güzel piyano çalar.
C. Kadının çantasını çalıp kaçmış.
D. Ekmeğin üzerine yağ çaldı.

5. "İşkence yaptıkça bana gülerdi." dizesinde anlatılmak istenen aşağıdakilerden hangisidir?
A. Toprak işlendikçe daha verimli hale gelir.
B. Kötülüğe iyilikle karşıllı vermek gerekir.
C. Her zaman güler yüzlü olunmalıdır.
D. Toprak sadık bir yârdir.

6. Aşağıdakilerden hangisi şairin vermek istediği mesajlardan biri değildir?
A. Toprağ 1 işlerseniz, o size ihtiyacınız olanı verir.
B. Topraktan geldik toprağa gideceğiz.
C. Allah'ın gizli hazinesi topraktır.
D. Toprak insanların kusurlarını gizleyemez.

Aşağıdaki ifadelerden doğru olanlara $D$, yanlış olanlara $Y$ yazınız.

7. Dinlediğiniz türküde yöresel ifadeler kullanılmamıștır.

8. Dinlediğiniz türküde toprağın önemi, değeri ve insan hayatındaki yerinden söz edilmemiștir.

9. Türküde ahengi sağlamak için mısra sonu tekrarları kullanılmıştır.

Aşağıdaki soruları cevaplayınız.

10. İzlediğiniz şiirdeki anahtar kelimelerden hareketle şiire yeni bir dörtlük yazınız? (10 puan) 


\section{1. İzlediğiniz videoda şairin hayatının hangi kesitinden görüntüler yer almaktadır? (10 puan)}

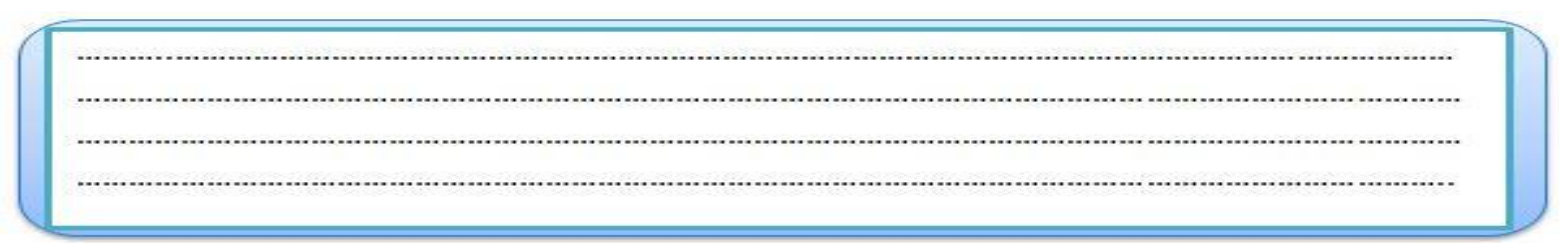

12. "Her kim ki olursa bu sırra mazhar

Dünyaya bırakır ölmez bir eser” dizelerinde anlatılmak istenen nedir? (10 puan)

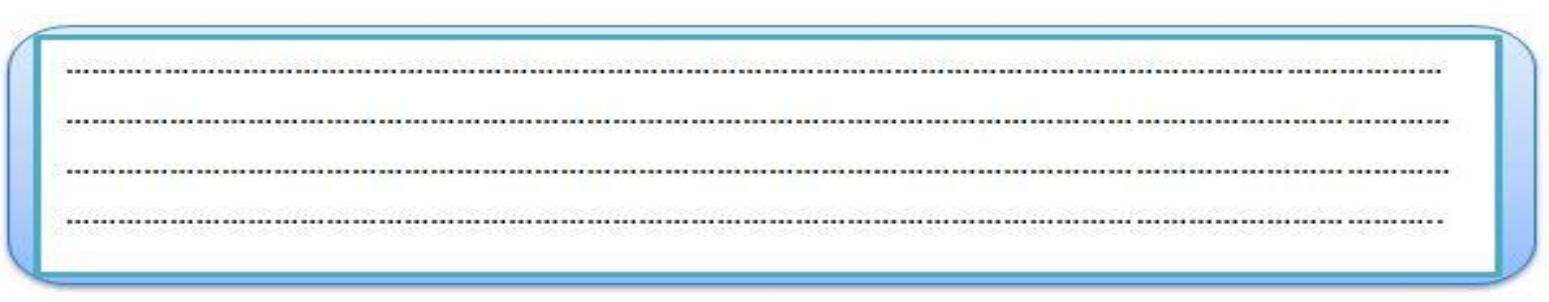

13. Siz olsaydınız bu türküye hangi baş̧ı̆̆ı koyardınız? Niçin? (6 puan)

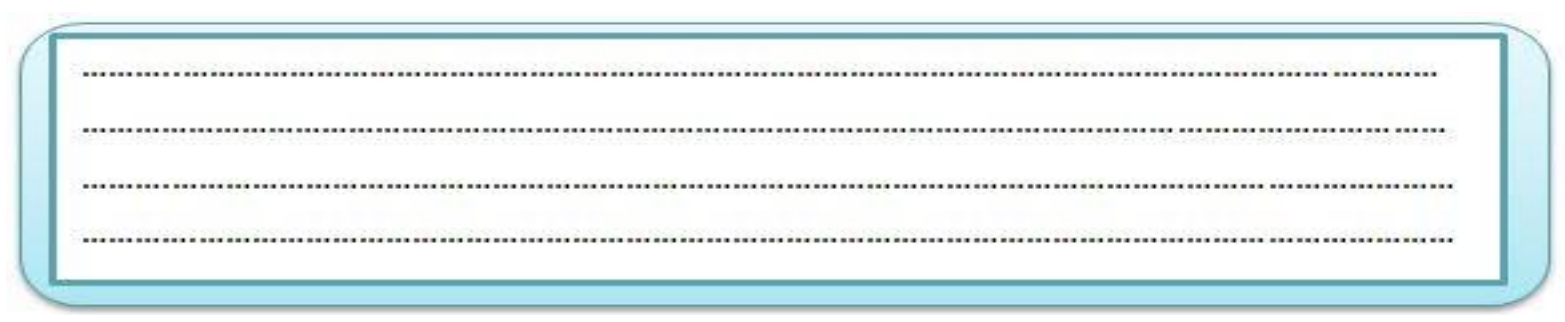

14. Size göre dünyadaki toprak alanlarının azalması ne gibi sorunlara yol açar? (10 puan)

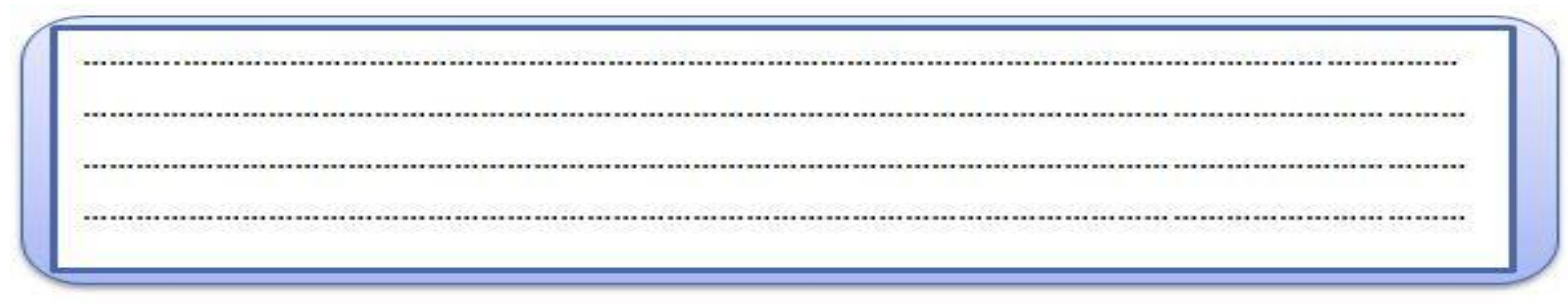

Not: Puanlamada 1-9 arası ve 13. soru 6 puan; diğer açık uçlu sorular 10 puandır. 


\section{ÖYKÜLEYİCI METIN BAŞARI TESTİ (BITTLISS KALESI)}

Aşağıdaki soruları dinlediğiniz metne göre cevaplayınız.

1. Aşağıdakilerden hangisi metnin kahramanlarından değildir?
A. Vezir
B. Büyük İskender
C. Hekim
D. Bitlis

I. Bitlis'in kalenin anahtarını İskender'e uzatması

II. Büyük İskender'in Çamapur ülkesini fethetmeye gitmesi

III. Büyük İskender'in yedi gün yedi gece uyumas1

IV. Büyük İskender'in Bitlis’i kalenin kumandanı yapması

2. Oluş sırasına göre sıralandığında yukarıdaki olaylardan hangisi sondan ikinci olarak gerçekleşmiştir?
A. I
B. II
C. III
D. IV

3. Bitlis'in Büyük İskender'e kalenin kapısını açmamasının nedeni aşağıdakilerden hangisidir?
A. Büyük İskender'e başkaldırması
B. Büyük İskender'in emrini yerine getirmesi
C. Büyük İskender'den korkması
D. Büyük İskender'in düşmanlarına esir düşmesi

4. Büyük İskender, Bitlis’ten bir kale yaptırmasını niçin istemiştir?
A. Kalenin bulunduğu yer askerî açıdan önemli olduğu için.
B. Kalenin bulunduğu yerin büyüleyici bir manzarası olduğu için.
C. Seferden döndükten sonra dinlenmek için.
D. Bölge halkını etkilemek için.

5. Büyük İskender, Bitlis'in hangi hamlesinden sonra kaleyi almaktan vazgeçip geri dönmüşsür?
A. Mancınıklarla ordunun üzerine taş yağdırması
B. Mazgallardan ok attırmas
C. Kale kapısından serçe büyüklüğünde böcekler yollaması
D. Tüm saldırılara karşı saldırılarla cevap vererek onları canından bezdirmesi

6. Bu metinden Büyük İskender ile ilgili aşağıdakilerden hangisi çıarılamaz?
A. Gücüyle tüm dünyaya nam salmıştır.
B. Anadolu'yu baştanbaşa geçmiştir.
C. Makedonyalıdır.
D. Bitlis Kalesi'ni zorla ele geçirmiştir.

7. Anlam ilişkisi bakımından aşağıdaki kelimelerden hangisi diğerlerinden farklıdır?
A. Nöbetçi-Kolcu
B. Güçlü-Güçsüz
C. Sağlık- Hastalık
D. Gece-Gündüz

8. Aşağıdakilerden hangisi Bitlis ile Büyük İskender'in ortak yönlerinden biridir?
A. İkisi de büyük kumandanlardır.
B. İkisi de çok cesurdur.
C. İkisi de merhametlidir. 
D. İkisinden de herkes korkar.

\section{Aşağıdaki yerlerden hangisi metinde yer almaz?}

A

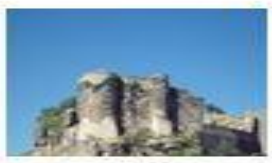

Bitlis Kalesi

C.

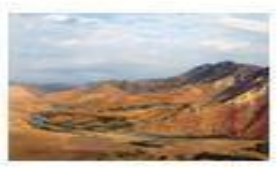

Muş Ovası
B.

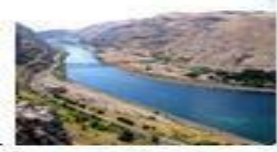

Firat Nehri

D.

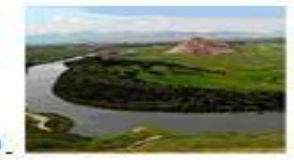

Dicle Kiyisi

Büyük İskender, askeri Bitlis'i yanına çağıııp ondan kendisinin bile saldırdığında alamayacağı bir kale yaptırmasını istemiş̧tir. Bitlis, kumandanının emrini yerine getirmiştir. Büyük İskender, kırk gün kırk gece askerleriyle saldırarak Bitlis'in yaptırdığı kaleyi ele geçirmeye çalışmışır. Ancak başarılı olamamıştır, vazgeçip dönmek üzereyken Bitlis kalenin anahtarını kumandanına teslim etmiştir. Büyük İskender de Bitlis'i cesur savunmasından dolayı kalenin kumandanı yapmıştır.

\section{Yukarıdaki parçadan aşağıdakilerden hangisi çıarılamaz?}

A. Büyük İskender Bitlis’ten çok sağlam bir kale yaptırmasını istemiştir.

B. Büyük İskender kaleyi ele geçirmek için kırk gün kırk gece saldırmıştır.

C. Büyük İskender Anadolu’yu baştanbaşa ele geçirmiştir.

D. Büyük İskender Bitlis’i cesur ve sözünün eri biri olduğu için kalenin kumandanı yapmıştır.

11. Dinlediğiniz metnin konusu aşağıdakilerden hangisidir?
A. Büyük İskender'in çok güçlü bir kumandan olması
B. Bitlis'in kaleyi inşa ederken yaşadığı zorluklar
C. Bitlis şehrinin adının nereden geldiği
D. Bitlis'in nasıl sadık ve cesur bir asker olduğu

12. Dinlediğiniz metne içeriğine uygun farklı bir başlık bulunuz. 
13. Siz Bitlis'in yerinde olsaydınız komutanınızın verdiği emri uygulamak adına ne yapardınız?

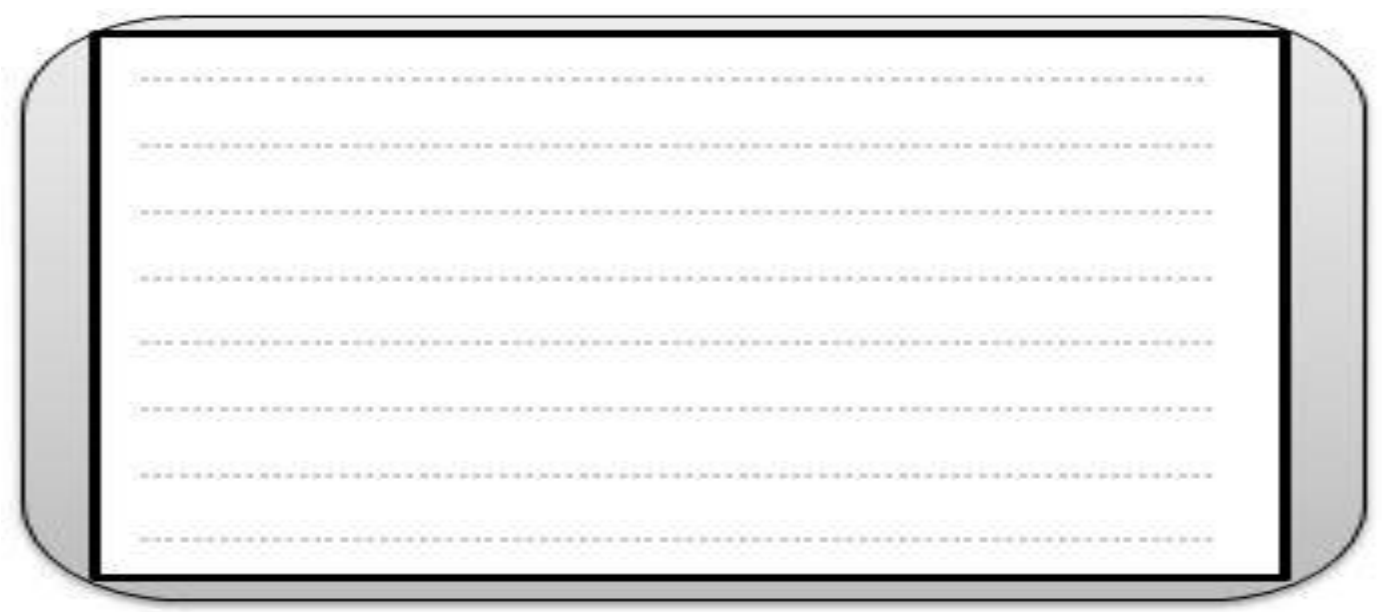

14. Siz Bitlis Kalesi’ne gidecek olsaydınız kalenin en çok neresini görmek isterdiniz? Niçin?

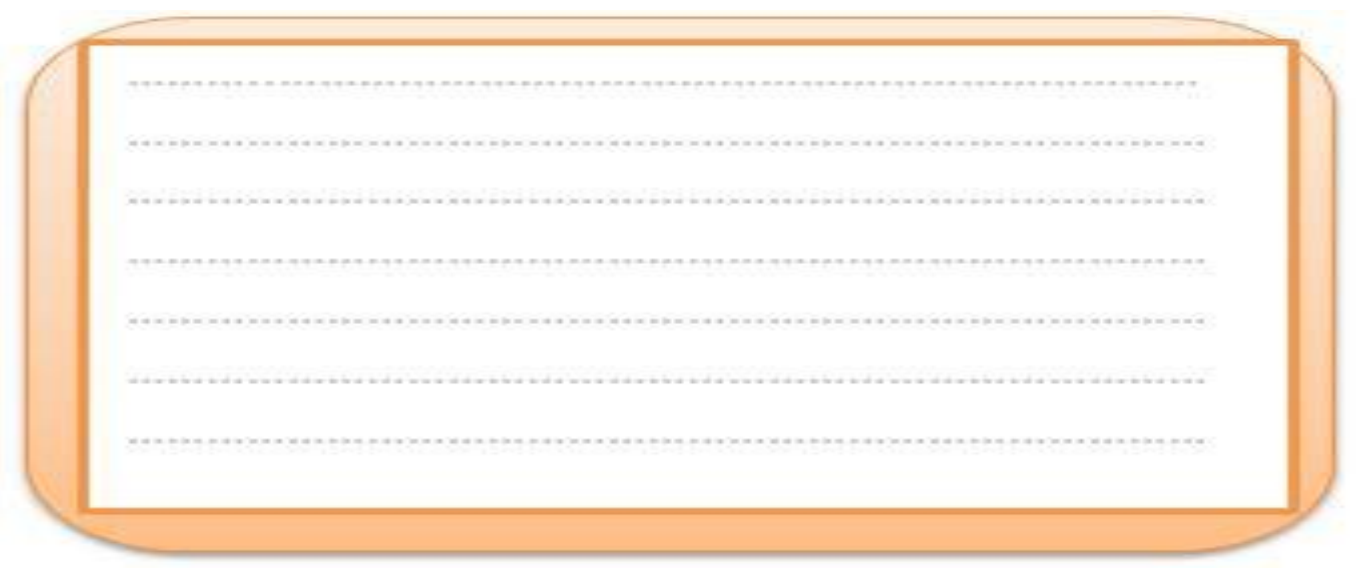

Not: Puanlamada ilk 11 soru 6 puan; 12. soru 4, 13 ve 14. soru 15 puan değerindedir. 


\section{BILLGILENDİRICI METIN BAŞARI TESTİ (GÜRÜLTÜ KİRLİLİĞí)}

Aşağıdaki soruları dinlediğiniz metne göre cevaplayınız.

1. Dinlediğiniz metne göre aşağıdakilerden hangisi gürültü kirliliğinin nedenleri arasında sayilmaz?
A. Kentleşme
B. Endüstrileşme
C. Küresel isınma
D. Teknolojik gelişmeler

I. Kişiyi bedensel ve ruhsal olarak olumsuz etkiler.

II. İnsanların işitme sağlığını ve duyduklarını algılamasını bozar.

III. Kişilerin birbirleriyle sosyalleşmelerini sağlar.

IV. Çevrenin sakinliğini yok ederek niteliğini değiştirir.

2. Dinlediğiniz metne göre yukarıda verilen cümlelerden hangileri gürültü kirliliğinin ortaya çıkardığı etmenlerdendir?
A. I-II-III-IV
B. III-IV
C. I-II-IV
D. I-II-III

3. Dinlediğiniz metne göre aşağıdakilerden hangisi gürültü kirliliğinin insanlar üzerindeki olumsuz etkilerinden biri değildir?
A. Havadaki zararlı gazlardan dolayı nefes alıp vermek zorlaşır.
B. İnsan birçok şeye fizyolojik olarak uyum sağlarken gürültüye uyum sağlayamaz.
C. Vücut gürültüye psikolojik tepki gösterir.
D. Ani ve şiddetli gürültü 3-4 günlük geçici işitme kaybına neden olur.

4. Aşağıdaki cümlelerden hangisi nesnel bir yargı içermektedir?
A. Uçak ve demir yolu araçlarının yarattığg gürültü, ses kirliliğinde çok önemlidir.
B. Gürültülü yerlerde çalışan işçilerde verimlilik yüzde 30 ile yüzde 60 oranında azalıyor.
C. Gürültüsü çok olan hastanelerde yatan hastalar iyileşemez.
D. Gürültü insan sağlığını derinden etkileyen faktörlerin başında gelir.

5. Dinlediğiniz metinde aşağıdaki sorulardan hangisinin cevabı yoktur?
A. Gürültü kirliliği ne demektir?
B. Gürültü kirliliğini gidermenin yolları nelerdir?
C. Gürültü kirliliğinin hayvanlar üzerindeki etkileri nelerdir?
D. Gürültü kirliliğinin neden olan etmenler nelerdir?

6. Dinlediğiniz metne göre aşağıdakilerden hangisi gürültü kirliliğini engellemenin yollarından biri değildir?
A. Otomobil kullanımını azaltma
B. Ev ve iş yerlerinde ses yalıtımı yapma
C. İki yol arasına çalı ve ağaç karışımı bitkiler dikme
D. Hastaneleri şehir merkezinden uzağa taşıma

7. Dinlediğiniz metne göre havaalanı ve otoyol çevrelerinde yeşil kuşak (ağaçlandırma) yapılmasının amacı aşağıdakilerden hangisidir?
A. Güzel bir manzara olușturmak
B. Gürültü kirliliğini önlemek
C. O bölgelerdeki insanlar için yaşam alanı olușturmak
D. Trafik kazalarını önlemek

8. Dinlediğiniz programın adı aşağıdakilerden hangisidir?

A. Yeşil hayat $\quad$ B. Mavi Bir Dünya C. Yeşil Dünyamız D. Yeşil Kuşak 
Aşağıdaki ifadelerden doğru olanlara D, yanlış olanlara Y yazınız.

9. Bitkilerin sesi emme ve yansıtma özelliği vardır.

10. Gürültü ve ses kirliliği birbirinden farklı kavramlardır.

11. Gürültü kirliliği cadde ve yol kenarlarına kısa bitkiler dikilerek önlenebilir.

Aşağıdaki soruları cevaplayınız.

12. Dinlediğiniz metne içeriğine uygun farklı bir başılı bulunuz.

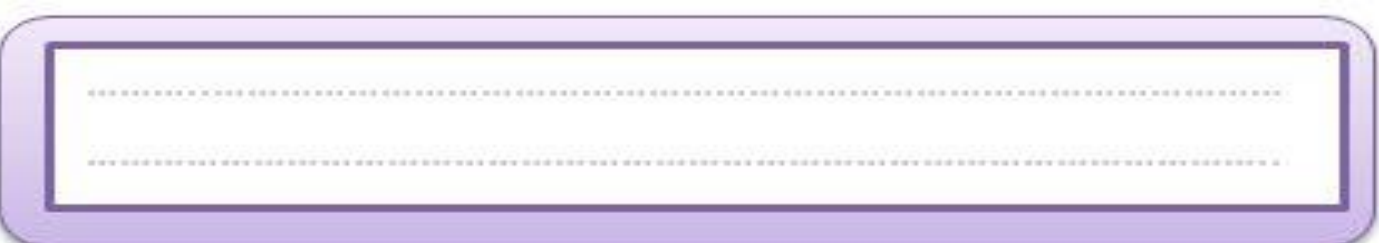

13. Sizce gürültü kirliliğinin engellenmemesi ne gibi sorunlara yol açabilir?

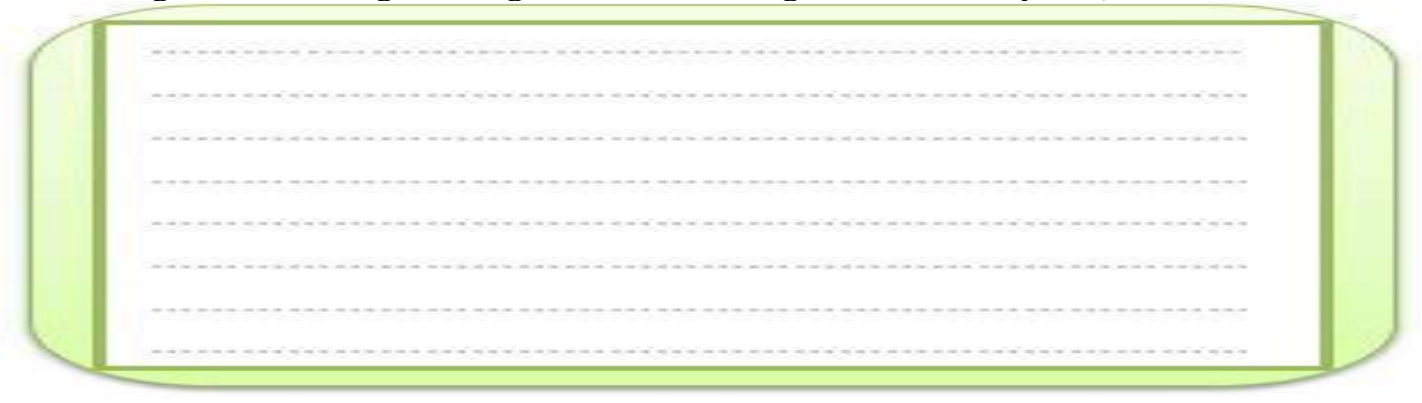

14. Siz günlük hayatınızda gürülttï kirliliğini engellemek için neler yapıyorsunuz?

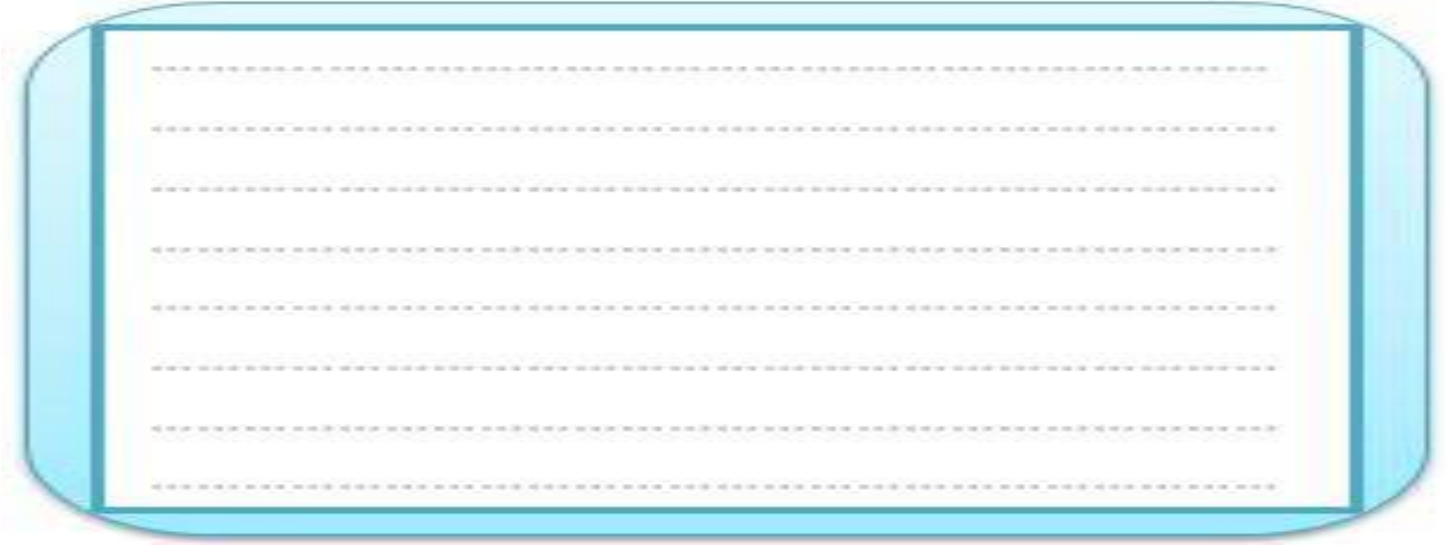

Not: Puanlamada ilk 11 soru 6 puan; 12. soru 4, 13 ve 14. soru 15 puan değerindedir. 


\section{Ek 2. Belirtke Tablosu}

\begin{tabular}{|c|c|c|c|c|}
\hline & Kazanum cümleleri (MEB,2006) & ȘM & ÖM & BMI \\
\hline \multirow{3}{*}{ 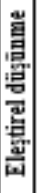 } & Dinlediklerini/izlediklerini kendi hayatı ve günlük hayatla karșılaştınr. & 14 & 14 & 14 \\
\hline & Dinlediklerinde/izlediklerinde ortaya konan sonunlara farklı çözümler üretir. & & 13 & 14 \\
\hline & Dinlediklerine/izlediklerine ilişkin sorulara cevap verir. & 14 & 13.14 & 13.14 \\
\hline \multirow{14}{*}{ 㲧 } & Dinlediklerini/izlediklerini içerik yömünden değerlendirir. & s & 10 & 5 \\
\hline & Dinlediklerini/izlediklerini dil ve anlatım yōnünden değerlendirir. & 7.9 .10 & & \\
\hline & Dinlediklerindeki/izlediklerindeki örtülü anlamlan bulur. & 2.4 .5 .12 & & \\
\hline & Dinlediği/izlediği metne farklı başlıklar bulur. & 13 & 12 & 12 \\
\hline & Dinlediklerindeki/izlediklerindeki anahtar kelimeleri fark eder. & 10 & & \\
\hline & Aym kavram alanma giren kelimeleri, anlam farklılıklanm dikkate alarak kullanur. & 4 & & \\
\hline & $\begin{array}{l}\text { Dinlenen/izlenen metnin bağlamindan hareketle kelime ve kelime gruplarmın } \\
\text { anlamlarım çkarı. }\end{array}$ & 4 & & \\
\hline & $\begin{array}{l}\text { Kendisini şahıs ve varlık kadrostunun yerine koyarak olaylan, duygu, düșünce ve } \\
\text { hayalleri yorumlar. }\end{array}$ & 3 & & \\
\hline & Dinlediklerinde/izlediklerinde yer alan öznel ve nesnel yargları ayırt eder. & & & 4 \\
\hline & $\begin{array}{l}\text { Dinlediklerindeki/izlediklerindeki olay, yer, zaman, şahıs, varlık kadrosu ve bunlarla } \\
\text { ilgili unsurlan belirler. }\end{array}$ & & 8 & \\
\hline & Dinlediklerindeki/izlediklerindeki yardımcı fikirleri/duyguları belirler. & 3.6 & & \\
\hline & Dinlediklerinin/izlediklerinin konusumu belirler. & s & 11 & \\
\hline & Dinlediklerine/izlediklerine ilişkin karşılaştırmalar yapar. & & 8 & \\
\hline & Dinlediklerine/izlediklerine ilişkin sorulara cevap verir. & $\begin{array}{c}2.3 .4 .5 .6 \\
.7 .8 .9 .10 \\
.12,13\end{array}$ & $\begin{array}{c}8.10,11, \\
12\end{array}$ & $4,5,12$ \\
\hline \multirow{9}{*}{ 雷 } & Görsel/işitsel unsurlarla dinledikleri/izledikleri arasında ilgi kurar. & & 9 & \\
\hline & Dinlediklerini/izlediklerini kronolojik sıra ve mantık akışı içinde özetler. & & 2.5 & \\
\hline & Dinlediklerinde/izlediklerinde amaç-sonuç iliş̧kilerini belirler. & & 4 & 6.7 \\
\hline & Dinlediklerinde/izlediklerinde sebep-sonuç ilişkilerini belirler. & & 3 & 2.3 \\
\hline & $\begin{array}{l}\text { Dinlediklerindeki/izlediklerindeki olay, yer, zaman, şahıs, varlık kadrosu ve bunlarla } \\
\text { ilgili unsurlan belirler. }\end{array}$ & & $1,6.8$ & \\
\hline & Dinlediklerini/izlediklerini içerik yömünden değerlendirir. & 11 & & 1.9 .11 \\
\hline & İpuçlarndan hareketle dinlediklerine/izlediklerine yönelik tahminlerde buluunur. & 11 & & \\
\hline & Dinlediklerine/izlediklerine ilişkin sorulara cevap verir. & 1.11 & $\begin{array}{c}1,2.3,4,5 \\
.6,7.9\end{array}$ & $\begin{array}{l}1.2,3.6,7 \\
.8 .9 .10 \\
11\end{array}$ \\
\hline & $\begin{array}{l}\text { Kelimeler arasmdaki anlam ilişkilerini kavrayarak birbiriyle anlamca ilişkili } \\
\text { kelimelere örnek verir. }\end{array}$ & & 7 & 10 \\
\hline
\end{tabular}

